\title{
Fruits of World Youth Day 2016
}

\section{Introduction}

The World Youth Day, which I was honoured to organize in Krakow, became - thanks to the joyous arrangement of Providence - a great and multifaceted event of faith and culture, the scope of which went far beyond the local boundaries. In this short article, I would like to make an attempt to sum up this time, being aware that it is not yet a closed, accomplished time. Perhaps even one of the biggest fruits of this great event is its durability - a kind of supernatural abiding in the ever new, often unexpected, effects that it brings with time. The World Youth Day (WYD) was characterized by the fact that, in essence, it paved the way for other tasks after it was over, rather than at the very moment they were taking place.

That is why it is so difficult to summarize them. However, I would like to provide some input on the positive issues and fruits of WYD in Krakow, which I will try to present in four points:

(1) WYD: the experience of the Church,

(2) WYD: the experience of the community and its fruit in the hope of social renewal, 
(3) WYD: reaching out to people outside the Church,

(4) WYD: an impulse for a new evangelization.

\section{Fruits of World Youth Day}

\subsection{WYD - the experience of the Church}

Let's start with the fact that WYD in Krakow showed the beauty of the Church. For many, that was a lasting lesson about the Church, a kind of vivid and practical ecclesiology: WYD showed the Church, whose nature contrary to what is usually said about it - goes far beyond what is external. The WYD Church is a living community of God with people, and of the people among themselves.

Participants of central events presented such attitudes, that is, they highlighted numerous and spontaneous expressions of faith, with a special reference to the ministry of Saint Peter.

The young really ARE at the moment with the Pope who - through the prism of a simple faith - is for them a representative of the Lord Jesus on earth.

This great love and attachment that they showed to the Pope was moving, and proved that the Church is not a stranger to them, that they understand the Pope well, that they feel like him, that the Church is an important dimension of their lives.

Do not forget about enthusiastic listening to God's Word proclaimed by the Church. A number of catecheses gathered many young people who want the truth and its knowledge. They know that without the Word of God stored in the memory of the Church, there is no access to the fullness of the truth.

And what about the vast number of confessionals set up in various places in Krakow? Does it not testify to the fact that young members of the Church are engaged with God who is effective in the sacraments?

What stories can those confessionals recount! How great is their testimony of the faith of young people, their conviction that Jesus has "the words of eternal life" that he has a Spirit that forgives sins and gives life. 
Finally, the great number of ministers of the Eucharist, ordinary and extraordinary, speak loudly about the awareness of young people that, in the Eucharist is the highest expression of the humble and silent presence of a living God among people.

In the field of understanding the Church and its beautiful presentation in the world, WYD left strong convictions about the necessity of cooperation between priests and lay people. It is a good testimony of how lay people can live and co-create with the spiritual Church.

Many believers, thanks to WYD, could experience that the church is their own home and a place of dedicated work. This in turn led to greater identification with the ecclesial community.

I would like to emphasize here that all that I am writing about does not exist only in the sphere of theories and ideals.

WYD in Krakow not only expressed itself on the days of the celebration as a form of participation in catechesis, pilgrimages to the Sanctuary of Divine Mercy and to the sanctuary of Saint. John Paul II, in central events, but were shaped primarily in three years of preparation, and now after the end of WYD at work, leading up to WYD in Panama. Preparation was not limited only to dealing with organizational problems, but was also a time of reflection and prayer.

Let us mention initiatives such as the constant adoration of the Blessed Sacrament, periodic recollections and retreats organized on a regular basis.

All these initiatives find further continuation, now clearly in reference to the experiences of the past, but somehow, more and more present in the memory and desire of young people.

And one more important matter related to the mystery of the Church: WYD has strengthened the attachment of the faithful to their parish. Many of them very hospitably opened their thresholds for pilgrims. This has become an opportunity to identify more with parish communities.

WYD was also an opportunity for the parish to open up to a universal Church, which by its very nature is Catholic, for the mutual opening of the parish and individual faithful to each other.

Such is the Church of WYD: it is related to what is local and what is universal. 

hope of social renewal

I can testify that my Archdiocese and my city have indeed become different. WYD has given a beautiful and powerful impulse for change, especially in the field of expanding the awareness of our small local community. This change can be seen in the nostalgia with which people, believers and non-believers reminisce about the time of the meeting. They say that, often, for the first time, in a long time, they have seen that in a world that is said to suffer from closed-door disease, a disease of strangeness and indifference, there is still a real need to be together, meet, exchange and get together. WYDs are always a confirmation and strengthening of the importance of solidarity. It is precisely in this dimension that they are a kind of prophecy of hope that, in spite of everything, we do not live in the era of the "death of man" (Fukuyama); that even today one can create strong bonds with God and people. Such hope is creative and joyfully involved in creating the future.

\subsection{WYD: reaching out to people outside the church}

It should be added that in this regard the events of WYD have gone beyond the framework of the ecclesial community.

Central government and administration on the central and local levels, the academic and intellectual world were involved in the preparation of central events through the Symposium devoted to the papal encyclical Laudato Si', as well as the artistic world through the preparation of the great exhibition Mary, Mother of Mercy.

Therefore, the most important aspect is that many people who recognize themselves as unbelievers testify that WYD was also a great and significant event for them, in which they participated in various ways, although always with a joyful and burning heart. It must be admitted that even though some people were afraid of specific organizational problems (communication, order, etc.) before the central events themselves, they quickly learned during the celebration and meetings that they were not 
dealing with a dangerous crowd, but with crowds of young people, who want to manifest their faith and invite the whole world to it.

Many of those who were indifferent or did not identify with Christ and the Church have read it all as a beautiful, subtle and powerful call to rethink their lives.

It is impossible to overestimate the missionary importance of such a pulse.

\subsection{WYD: an impulse for a new evangelization}

The meeting of the young with Pope Francis influenced the young in such a way that strengthened in them the desire to undertake a new evangelization addressed to everyone, but especially to those who for various reasons are on the margins of social and ecclesiastical life.

It also strengthened us in the conviction that evangelization has the joyful face of meeting and community.

WYD convinces, with great power, that evangelization can never be treated as a pastoral technique.

What evangelizes is the unveiling of a beautiful, God-shaped humanity. How practically Paul's words have been confirmed that "creation awaits the appearance of the sons of God" (Rom 8:19)!

The experience of WYD encourages evangelization with a human face, evangelization through closeness and humanity. They are proof that it is humanity, when it is motivated and permeated with God, that becomes a word that is difficult to resist.

Finally, I would like to express my immense gratitude, especially to God, for the great gift of WYD in Krakow. To Saint John Paul II, thank you for the idea and, how very much felt, care at every moment of this event of faith.

A special thank you to Holy Father Francis, who was drawn with his paternal sensitivity in the experience of the WYD

My warm thanks also to all of you who have worked generously on their behalf.

I am asking God that Krakow's WYD would bring new fruit. May the feast of faith of the young continue to bear fruit! 
